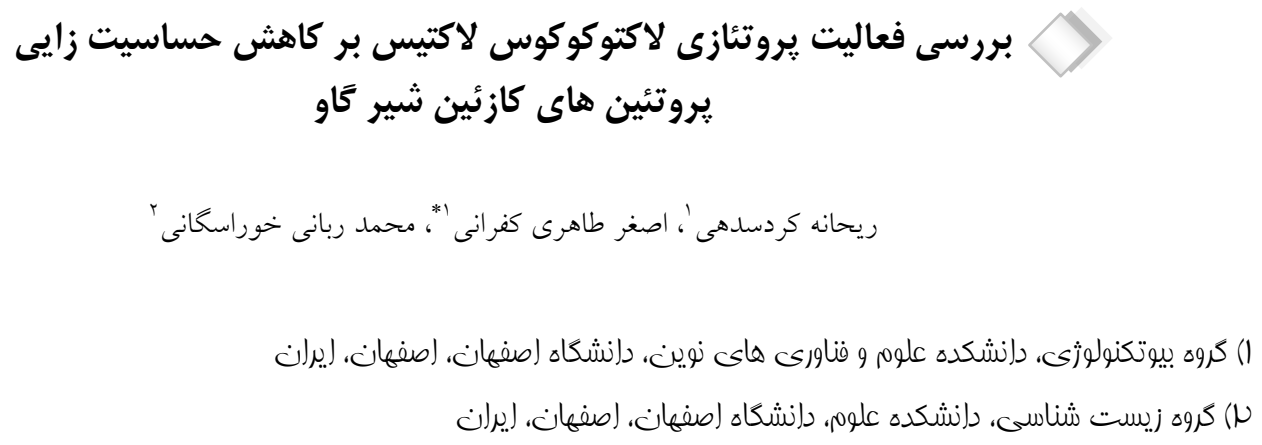

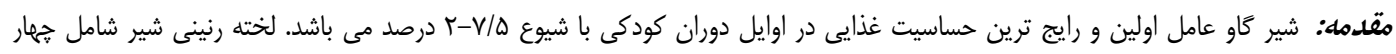
يروتئين اصلى

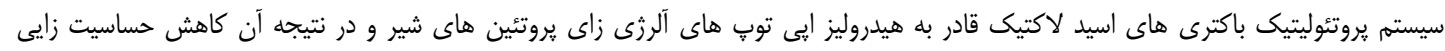

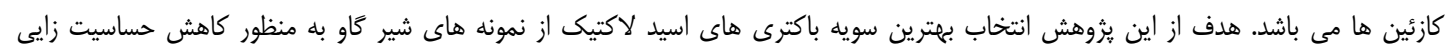

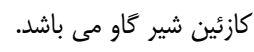

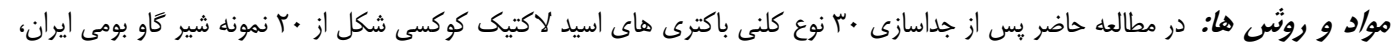

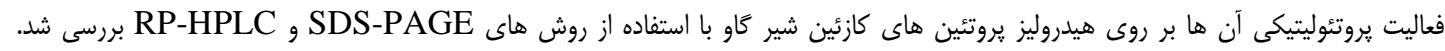

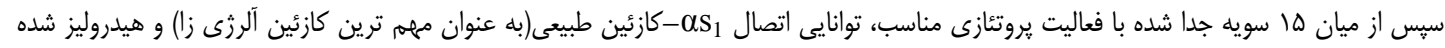

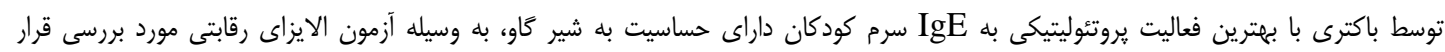

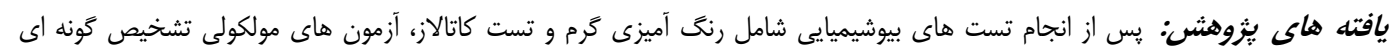

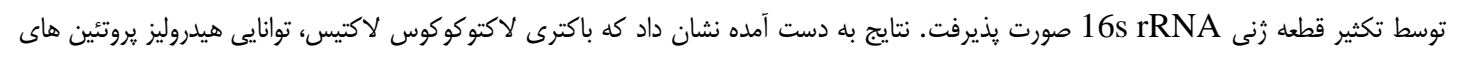

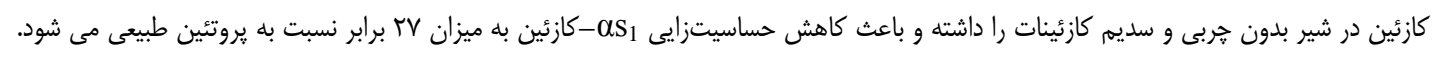

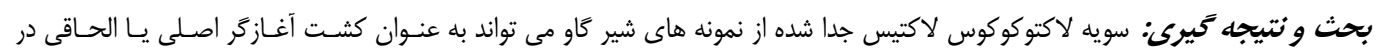

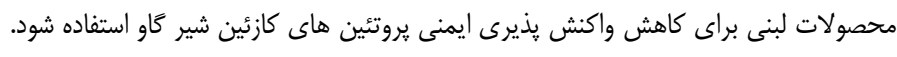

وازه هاى كليدى: حساسيت غذايى، كازئين، باكترى هاى اسيد لاكتيك، الايزاى رقابتى

* نويسنده مسئول: كروه بيوتكنولوزى، دانشكده علوم و فناورى هاى نوين، دانشخاه اصفهان، اصفهان، ايران

Email: a.taheri@ast.ui.ac.ir

Copyright () 2018 Journal of Ilam University of Medical Science. This is an open-access article distributed under the terms of the Creative Commons Attribution international 4.0 International License (https://creativecommons.org/licenses/by-nc/4.0/) which permits copy and redistribute the material, in any medium or format, provided the original work is properly cited. 
يروتئوليتيكى يك نقش ضرورى در متابوليسم نيتروزن مقدمه باكترى هاى اسيد لاكتيك در شير ايفا مى كنند(9).

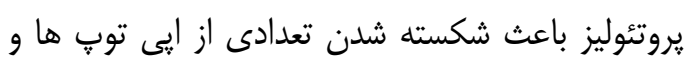

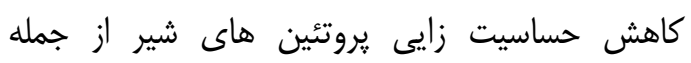

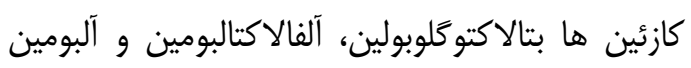

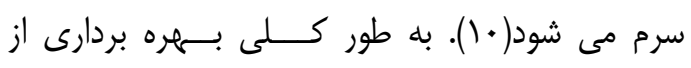

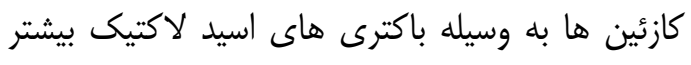

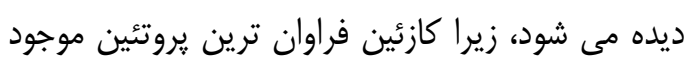

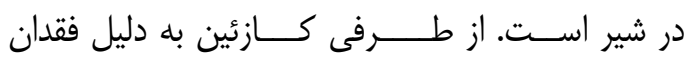

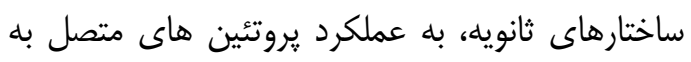

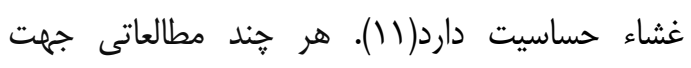

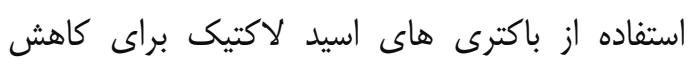
حساسيت شير كاو انجام شده است، تاكنون در ايران تنها در يك يزوهش توسط طاهرى كفرانى و همكاران فعاليت يروتئوليتيكى باكترى هاى لاكتوباسيلوس جند

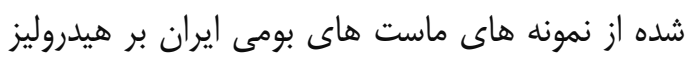

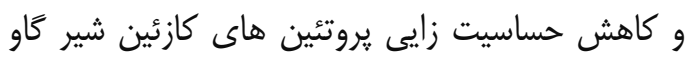

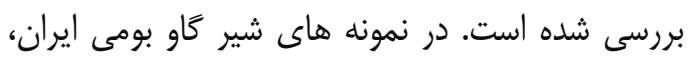

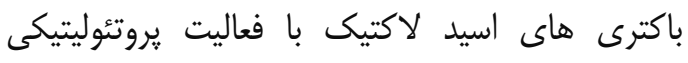
بسيار خوب وجود دارند اما تاكنون اثر هيدروليزى اين فئي باكترى ها بر يروتئين هاى حساسيت زاى شير كاو از

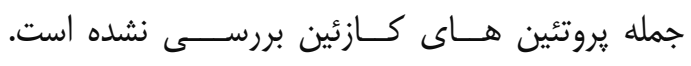

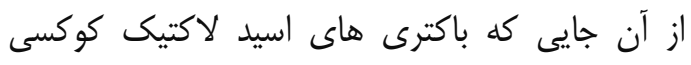

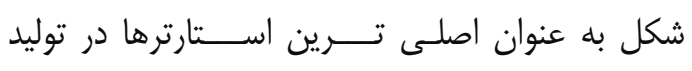

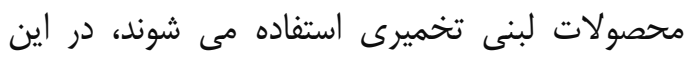

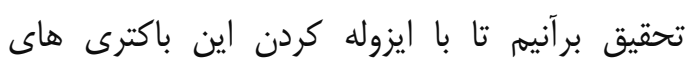

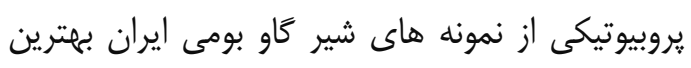

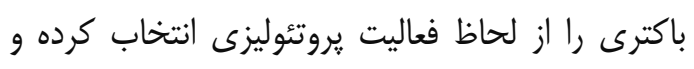

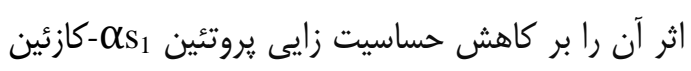

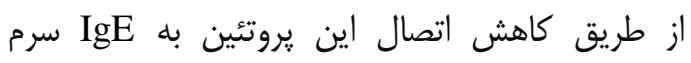

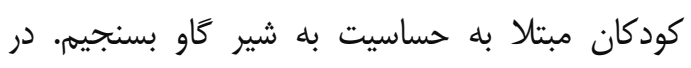

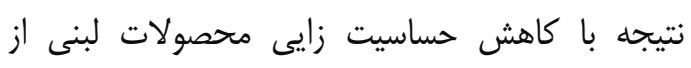

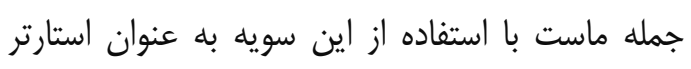

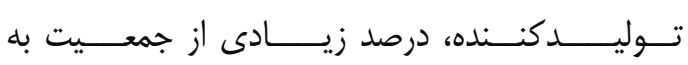

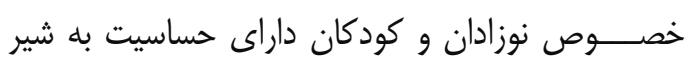

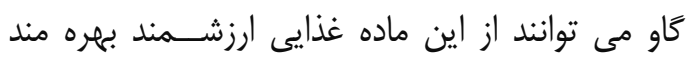

حساسيت غذايى يك ياسخ غير طبيعى سيسته ايمنى به تعدادى از يروتئين هاى مواد غذايى مى بـ باشد.

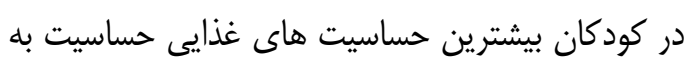
شير كاو، تخم مرغ، بادام زمينى، كَندم، سويا، آجيل هان هان

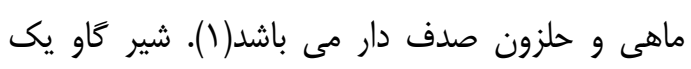

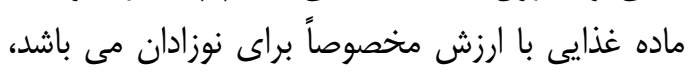

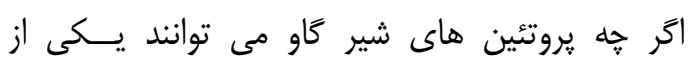
اصلى ترين آلرزن هاى غذايى بوده و واعث ناعث ايجاد

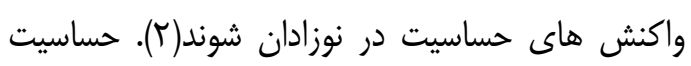

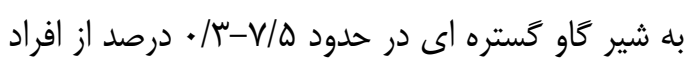

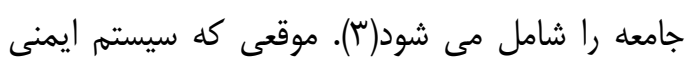

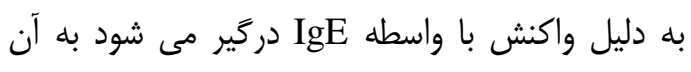

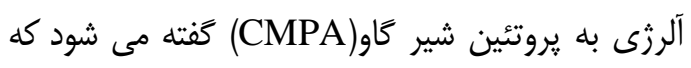

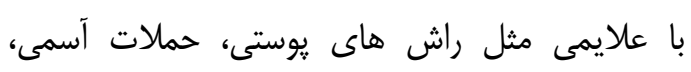
خارش، اسهال و ناراحتى هاى دستخاه توارشى همراه

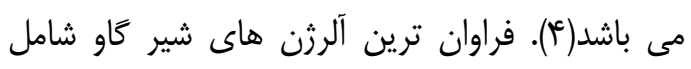

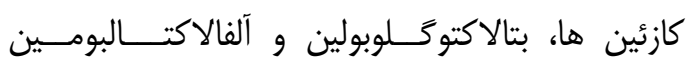

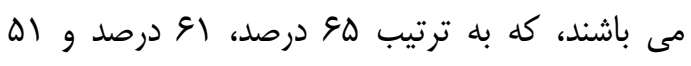
درصد از افراد به آن ها حساسيت دارئن دارند(ه). كازئين

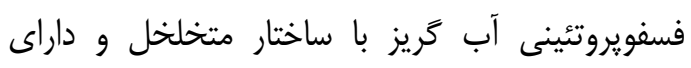

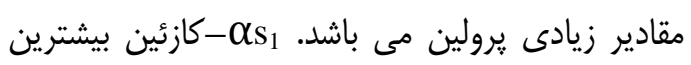

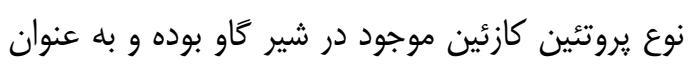

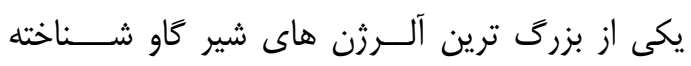

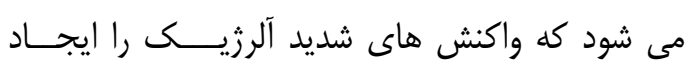

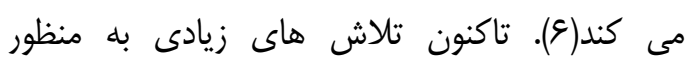

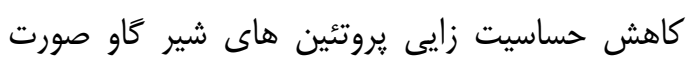

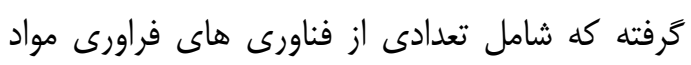
غذايى مثل كليكوزيلاسيون، تيمار حرارتى و هيدروليز

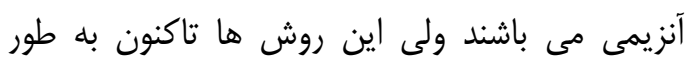

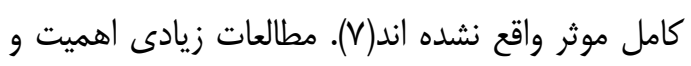
نقش بارز تخمير مواد غذايى توسط باكترى هاى اسيد الندان

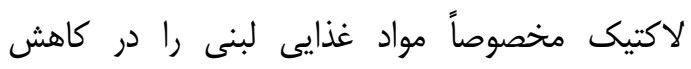

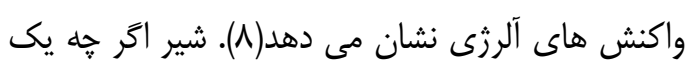
محيط رشد غنى بوده ولى مقادير اسيدهاى آمينه آزاد و ييتيدهاى كمى براى حمايت از رشد اين باكترى هادئ

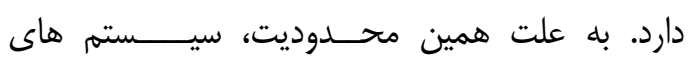


سيس بافر فسفات را روى رسوب باكترى ريخته و در

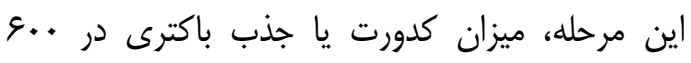

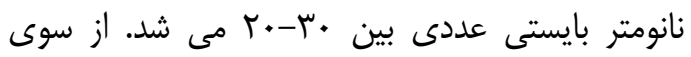

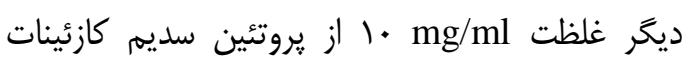

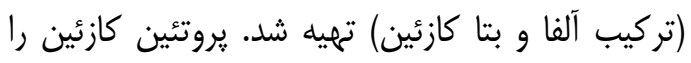

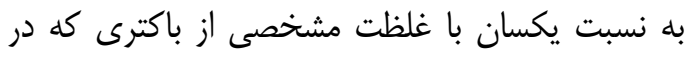

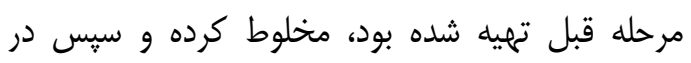

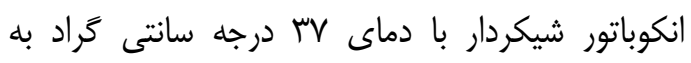

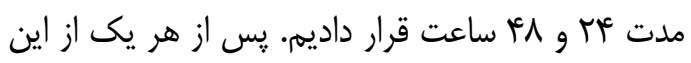

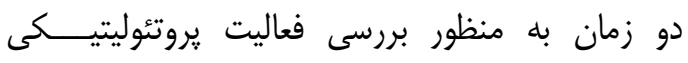

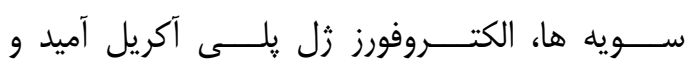
كروماتوگر افى ستونى انجام شد.

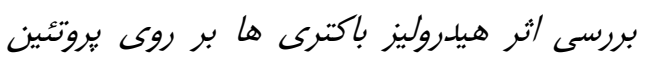

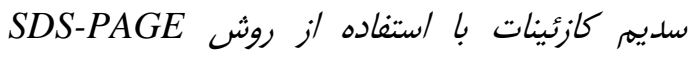

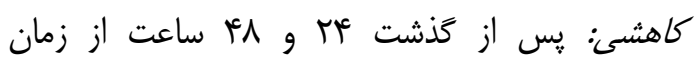
انكوباسيون نمونه ها، نسبت يكسان از ازئ محلول

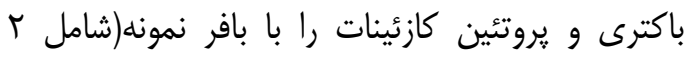

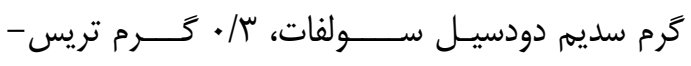

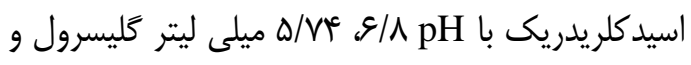

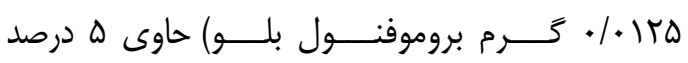



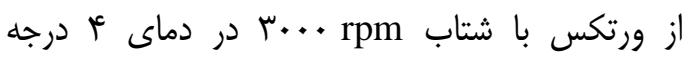

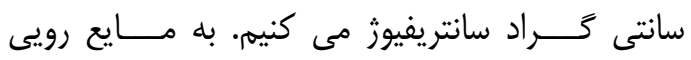
ويال هاى سانتريفيوز شده به نسبت يكسان بافئر بافر نمونه

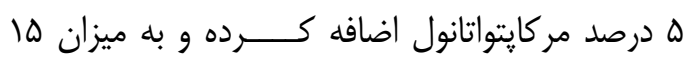

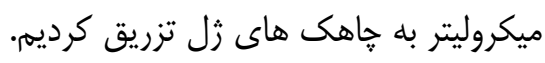

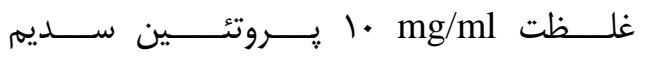

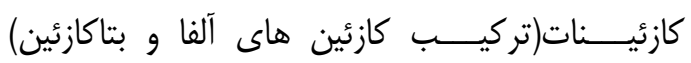
بدون باكترى نيز نقش نشان گر راد در زل الكتروفورز

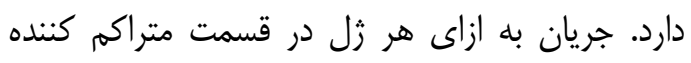

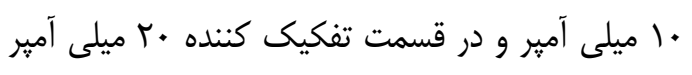

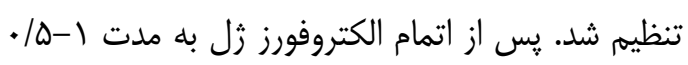

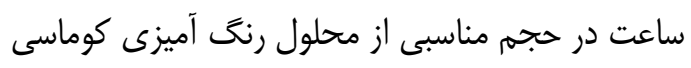

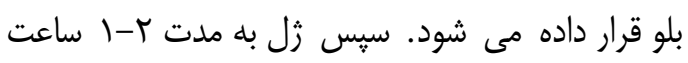
در محلول رنغ بر قرار داده شده تا رنى اضافه خارج

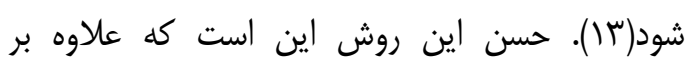

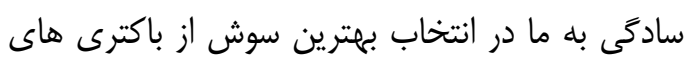

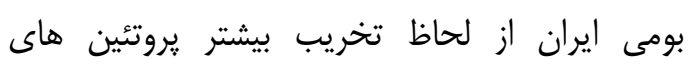

\section{مواد و روش ها}

باكترى هاى /سيد لاكتيك مورد اســـتفاده:

باكترى هاى اسيد لاكتيك از بيست نمونه شير لاسيك ماو

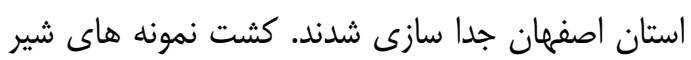

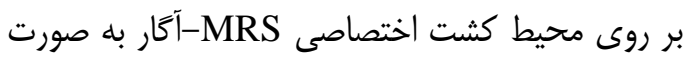

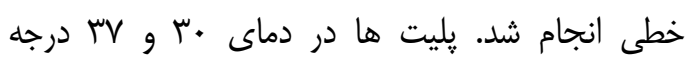

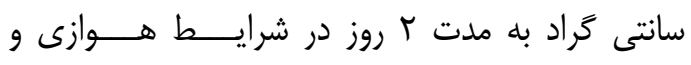

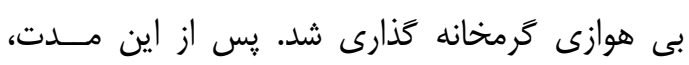

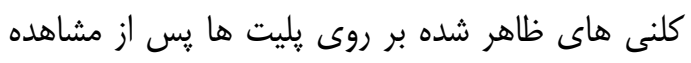

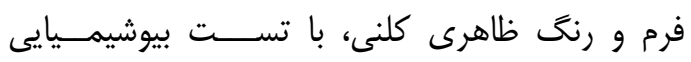

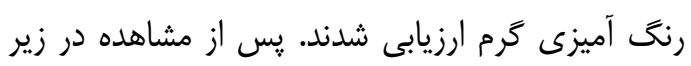

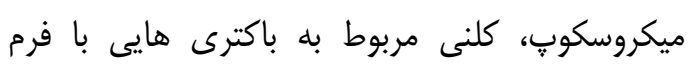

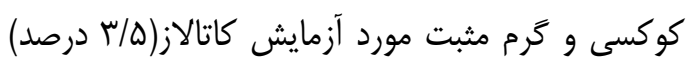

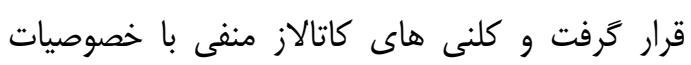

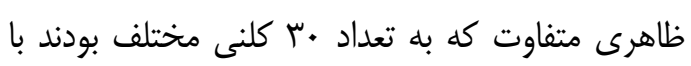
كشت هاى متوالى خطى خالص سازى شدند. بررسى هيدروليز بروتئين هاى كازئين شير كأي توسط كشت باكترى ها در محيط شير-سيترات-آكار: از

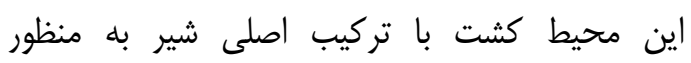

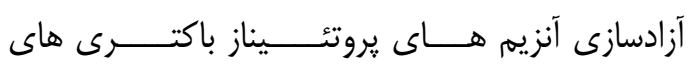
اسيد لاكتيى جهت هيدروليز يروتئين هاى شير ييش إني

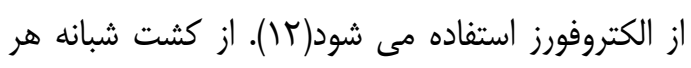
سويه باكترى در محيط MRS-براث جهت انتقال به اين محيط استفاده شد. بدين ترتيب كه يس از از تغليظ

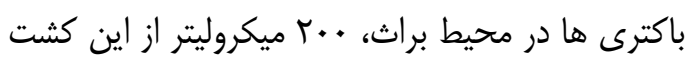

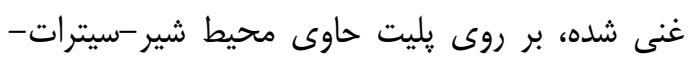

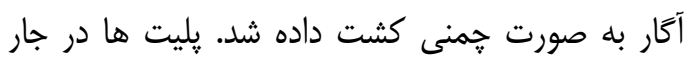

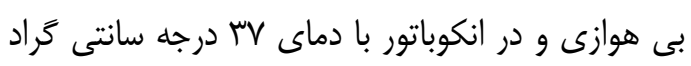
و به مدت ع ب ساعت نكمهدارى شده تا كلنى هايى سفيد

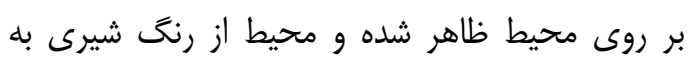
سفيد تغيير كند، كه نشان دهنده توليد آنزيم هاى هيدروليزى توسط باكترى هاى اسيد لاكتيى جهت استفاده از مواد مغذى موجود در محيط كشت مى باشئ.

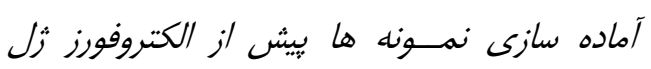
SDS-PAGE

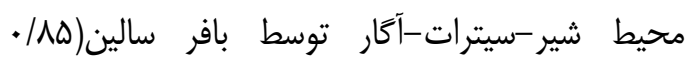

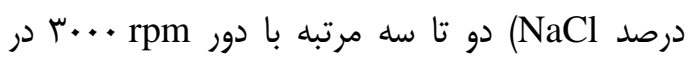
دماى محيط به مدت ها دقيقه شستشو داده شدند. 
شد. سرم ها به نسبت ا:.• در بافر اشباع رقيق شده بودند، تا رقيق شدن نهايى آن ها (:-•r شود. محدوده

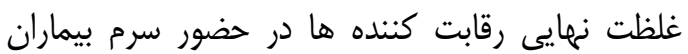

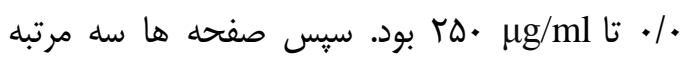

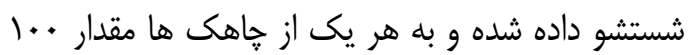

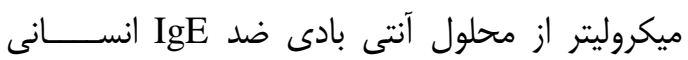
يلى كلونال جفت شده با فسفاتاز قليايى اضافه شد و به ليه

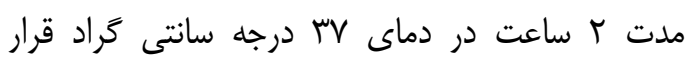
گرفت. يیيوند شدن آنتى بادى ثانويه بعد از س مرتبه

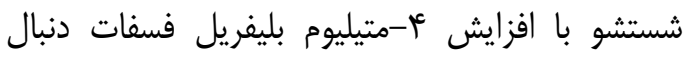

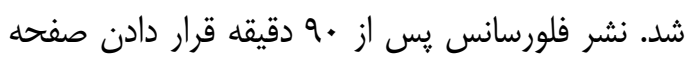

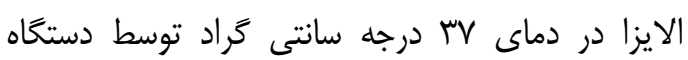

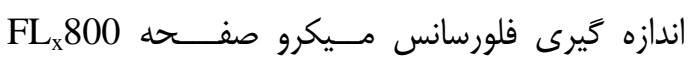
اندازه گيرى شد. طول موج تهييج •عس نانومتر اختيار

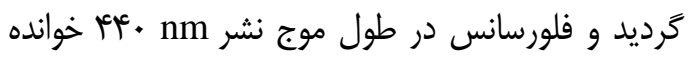

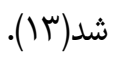
شناسايیى مولكولى سويه يروتئوليتيك توسط تكثير

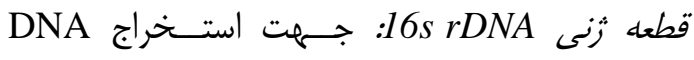
باكترى هاى اسيد لاكتيك از روش جوشاندن استفاده شد. به منظور تعيين غلظت و خلوص DNA استخراج

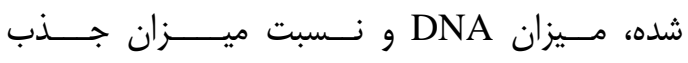
A260/A280 نمونه هاى استخراج شده توسط دستخاه

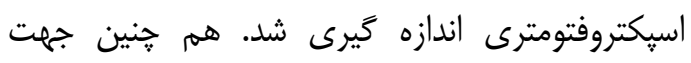

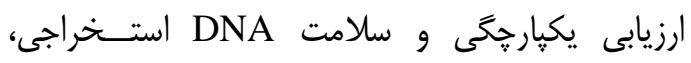
نمونه ها بر روى زل آكارز يك درصد مورد بررسى قرار

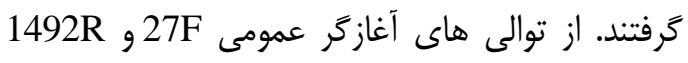
جهت PCR استفاده شد. آغازگرها يس از رقيق كردن

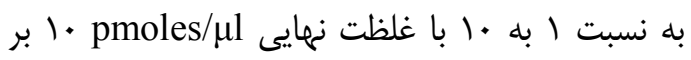
طبق يروتكل شركت سازنده مورد استفاده قرار گرفت.



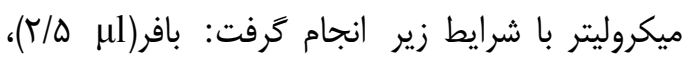
مايمرهاى رفت و

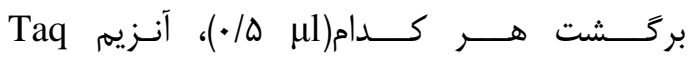

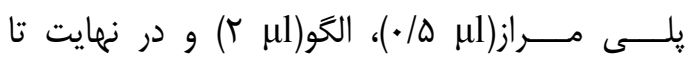
حجم ها ميكروليتر آب مقطر تزريقى اضافه شد. واكنش با جرخه هاى واسرشته سازى اوليه در هو درجه

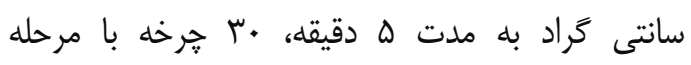

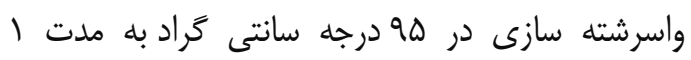

كازئين، جهت انجام آزمون كمى كروماتوگرافى كمى مى كند. بررسى اثر هيدروليز باكتريايى بر روى بروتئين

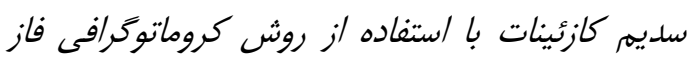

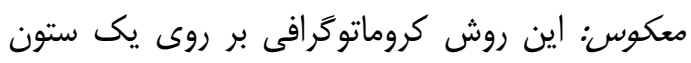

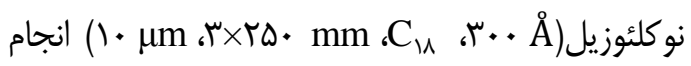

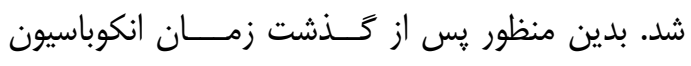
سويه هاى يروتئوليتيك جدا شده از نمونه هاى شير بان

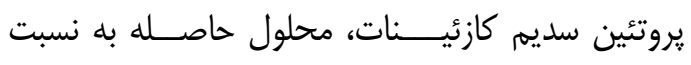

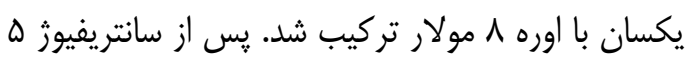

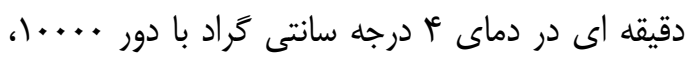
سويرناتانت حاصله به صورت مستقيم به ستون تزريق

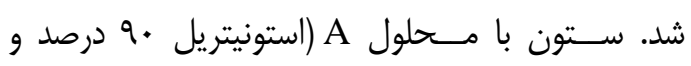
ترى فلئورواستيك اسيد / / • درصد) به تعادل رسيد. هم

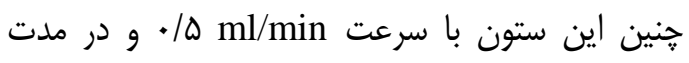

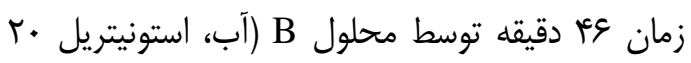

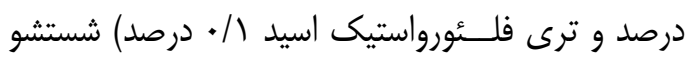
داده شد. دماى ستون و حلال ها بر روى •ب درجه

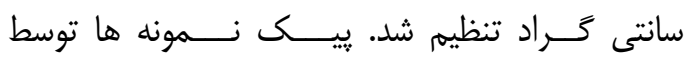
اندازه گيرى جذب در طول موج · بr و • •ب نانومتر

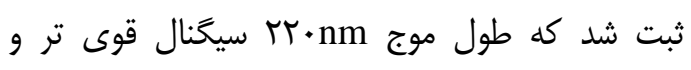
ييك هاى بهترى ارسال كرد. بررسى ميزان كاهش حساسيت زايى بروتئين كازئين توسط سويه الى با بهترين فعاليت بروتئوليتيكى مئى

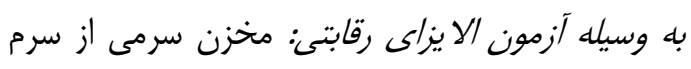

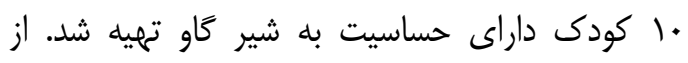
صفحه اى شامل و9 جاهك سفيد ته صاف، جهت انجام آزمايش استفاده گرديد. به هر يك از خاهل

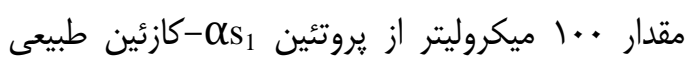
با غلظت بg/ml ه اضافه شد. در روز بعد، صفحه الايزا سه مرتبه توسط بافر شستشو PBS/T شامل بافر سديم

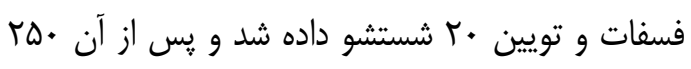

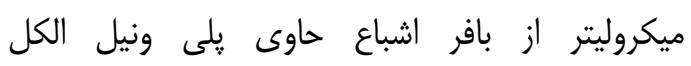

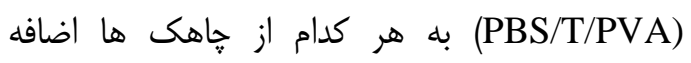

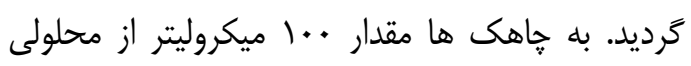
شامل مخلوطى از سرم افراد بيمار داراى حساسيت

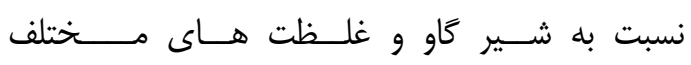
رقابت كننده ها(كازئين طبيعى و هيدروليز شده) افزوده 


\section{يافته هاى يزوهش}

سويه هاى خالص شده به فرم هاى مختلف از جمله كوكسى و باسيل بودند. لازم به ذكر است كه در بهر ميان نمونه هاى شير، مخمرها و لاكتوباسيلوس ها نيز جدا شدند. در نهايت از اين نمونه هاى شير كائ تاو تهير، مهيه

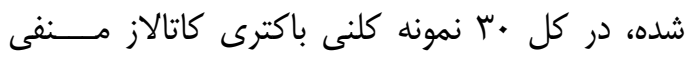

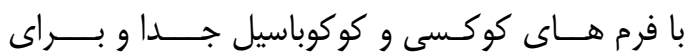

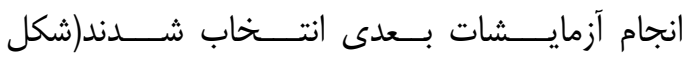

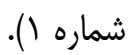

دقيقه، مرحله اتصال يرايمر در PV درجه سانتى گراد به

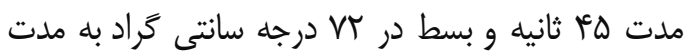

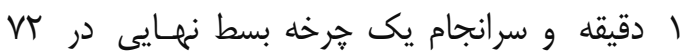

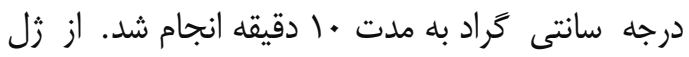
آكارز ا درصد جهت بررسى محصولات تكثير يافته و آشكار سازى محصولات در الكتروفورز استفاده شد. سيس محصول به دست آمده از PCR سويه هاى مورد نظر جهت تعيين توالى و شناسايى گونه باكتريايى به شركت زيست ويثن ايرانيان ارسال شد.

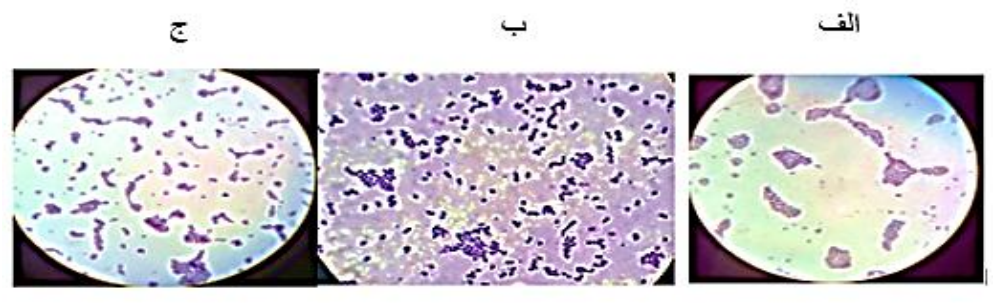

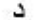

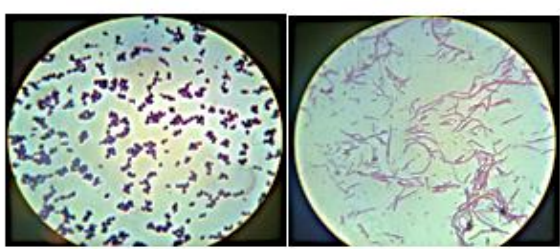

شكل شماره ا. تصوير ميكروسكويى سويه هاى جدا شده از نمونه هاى شير تاو ايرانى كه توسط رنحَ آميزى تَرم در زير

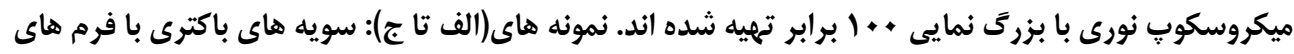

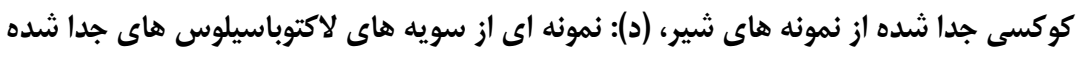

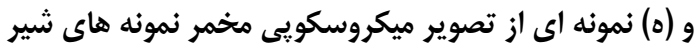

جدا شده از شير كاو نشان مى دهد كه اكثر سويه ها

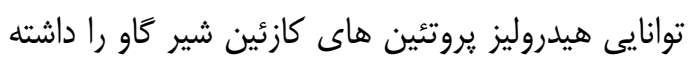
ولى در مورد يك سويه يس از تاب ساعت هيدروليز

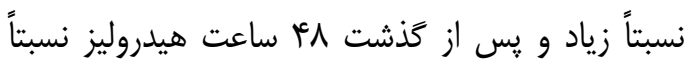

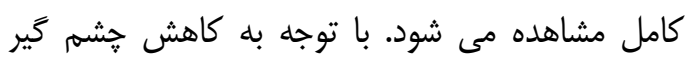

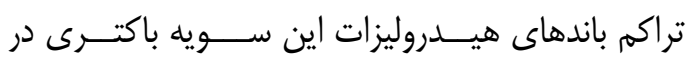

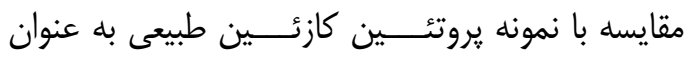
كنترل، اين سويه به منـــــور بررســـ دقيق تر براى HPLC
نتايج حاصل /ز هيلروليز باكتريايى بروتئين هاى

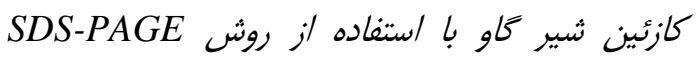
كاهشى: كاهش تراكم باندها در زل الكتروفورز، نشان دهنده هيدروليز توسط يروتئزهاى باكتريايى مى بـ باشد.

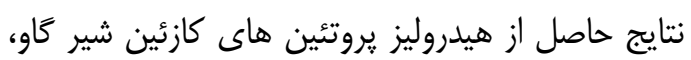

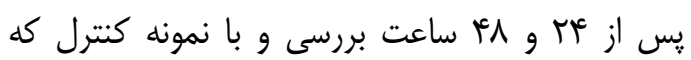
يروتئين هاى كازئين شير كاو بدون حضور يروتئاز

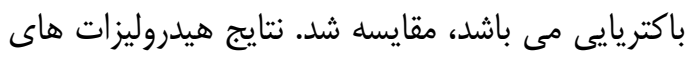

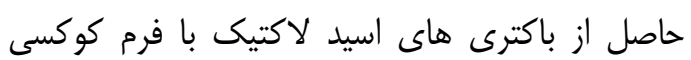




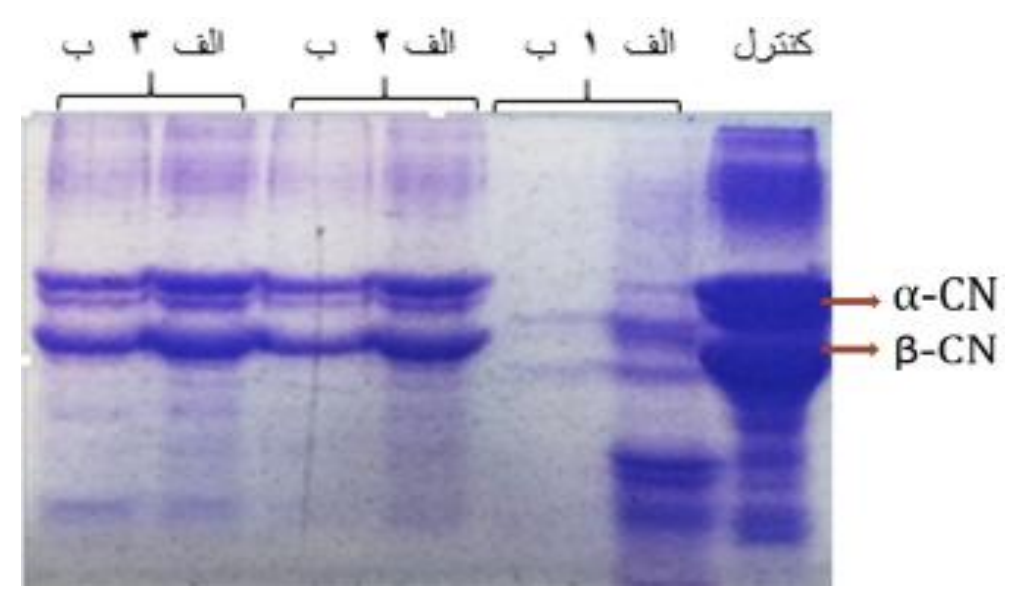

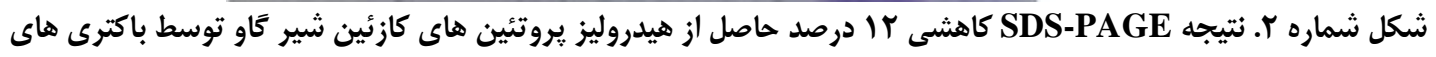

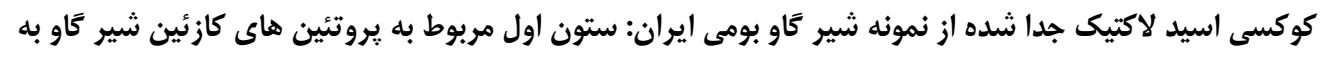

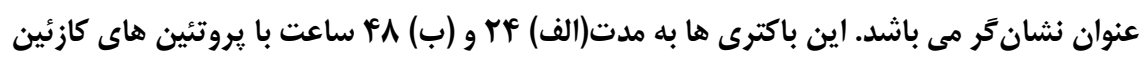

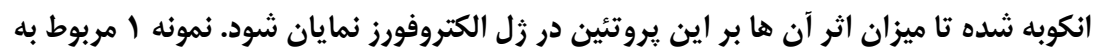



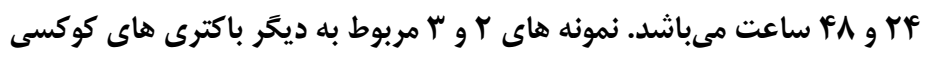

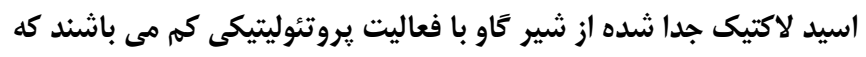

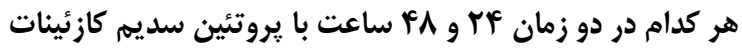
شير كاو انكوبه شده اند ساعت بان

توسط باكترى اسيد لاكتيك جدا شده از شير كاو با

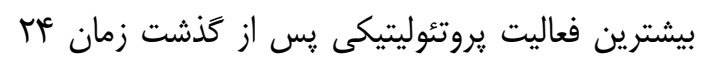

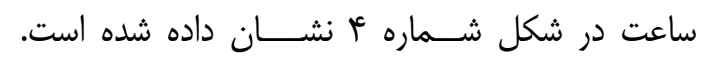

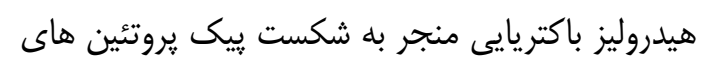

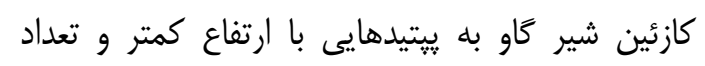
بيشتر مى شود. در نمونه هاى هيدروليز شده، از از زمان بان حدود ها-1 دقيقه بيكى هاى مربوط به هيد هيدروليزات

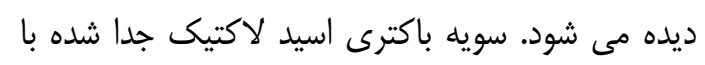

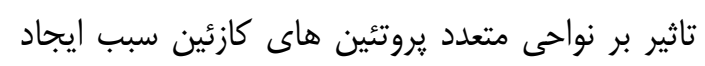

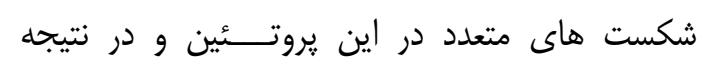

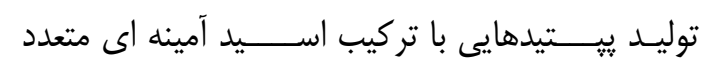
مى شود.
نتايج كروماتوكرافى فاز معكوس حاصل /ز هيدروليز

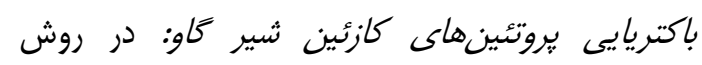

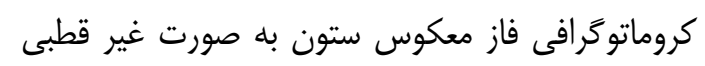

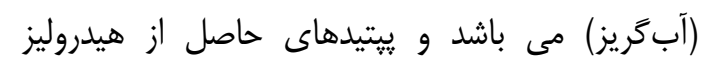

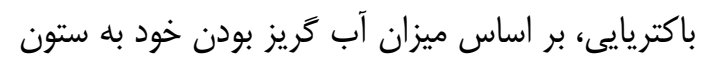
متصل مى شوند. كروماتوكرام نمونه هاى استاندارد و و

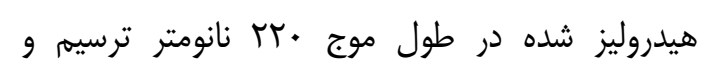

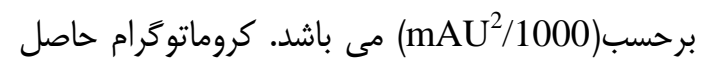

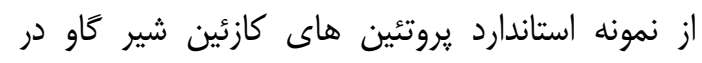

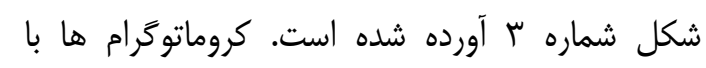

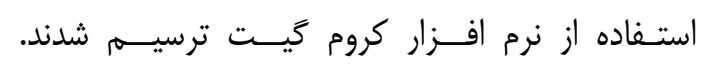
كروماتوكرام حاصل از هيدروليز يروتئين هاى كازئين ترسين 

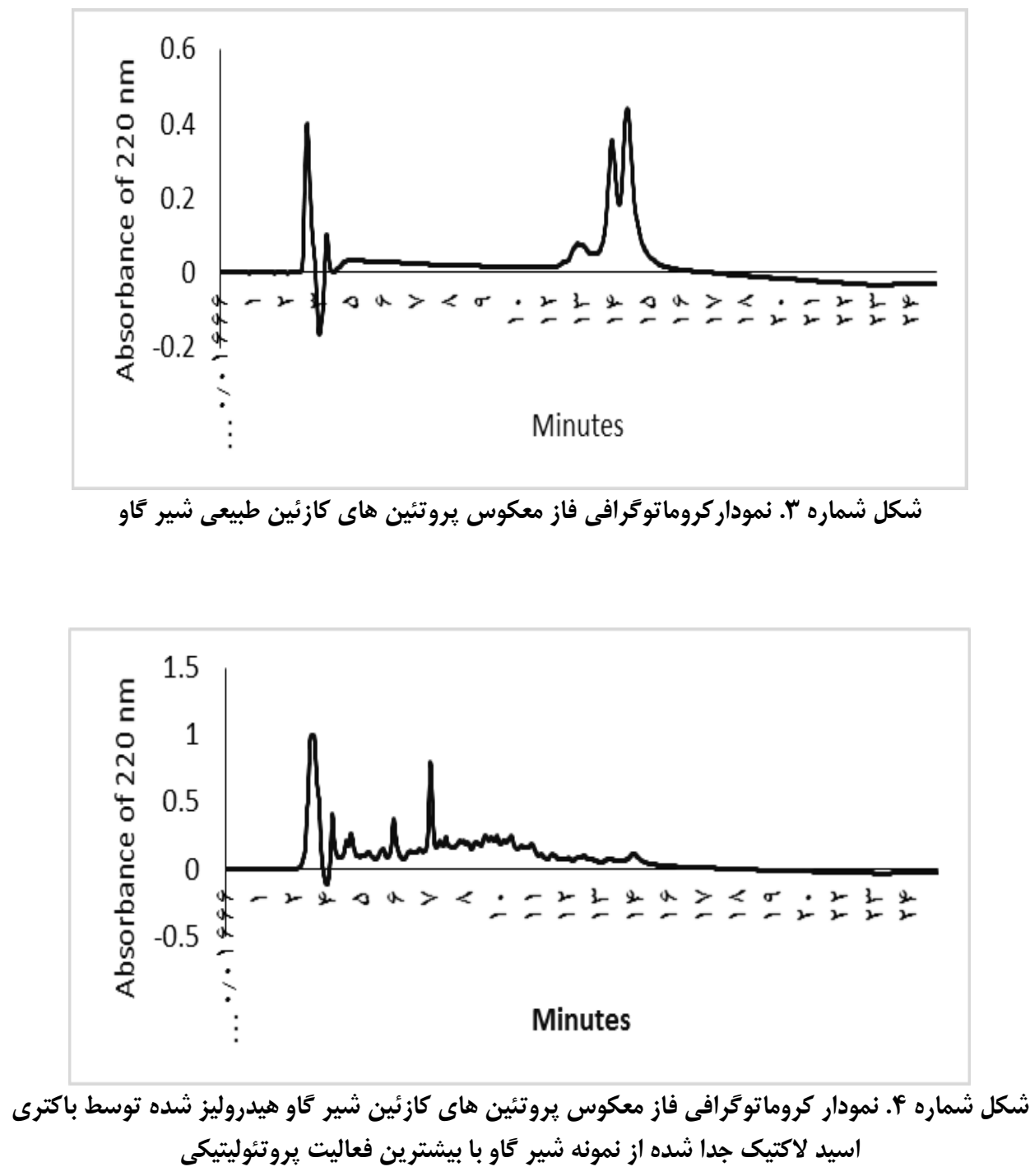

هيدروليزات به IgE سرم افراد بيمار نسبت به يروتئين

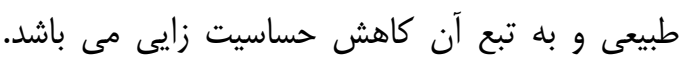

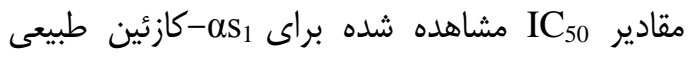

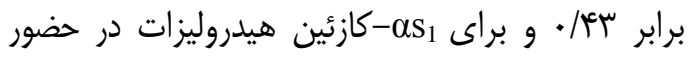
باكترى جدا شــــه از شـــير كاو با بيشترين فعاليت



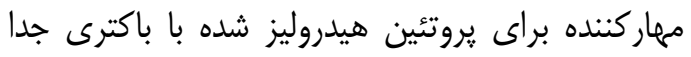
شده از شير كاو به ميزان TV برابر نسبت به يروتئين طبيعى كاهش نشان مى دهد، يعنى به همين ميزان باعث كاهش آلرزى شده است.

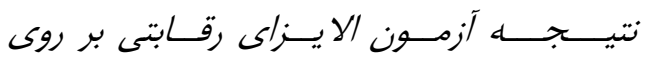

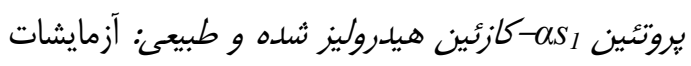
الايزاى رقابتى با استفاده از كل يروتئين هاى كازئين

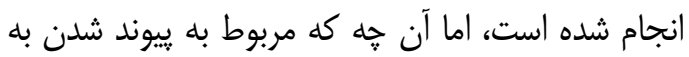

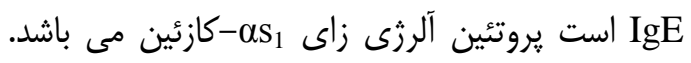

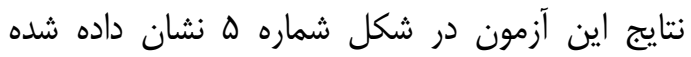

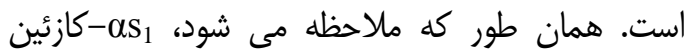
هيدروليزات نسبت به يروتئين طبيعى داراى يكى جا به

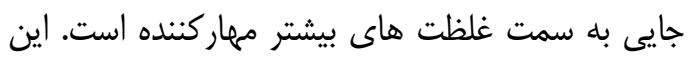

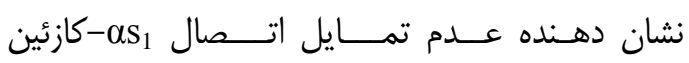




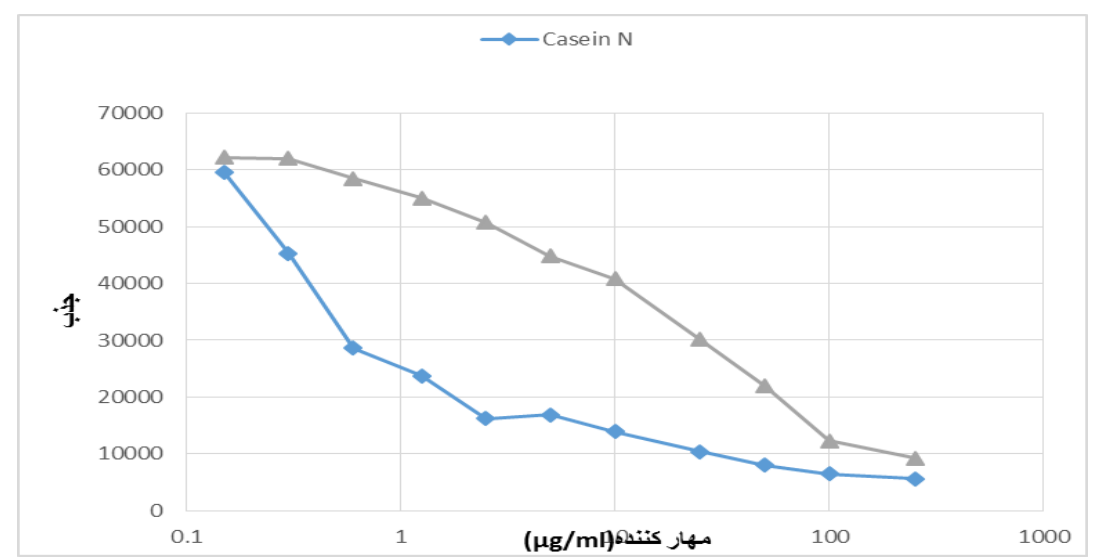

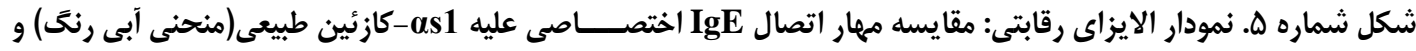

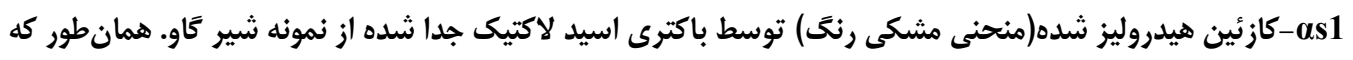

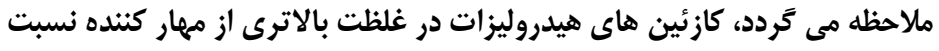

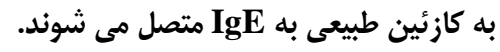

و نتايج حاصل از تعيين توالى سيس با استفاده از ابزار

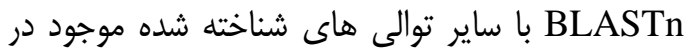

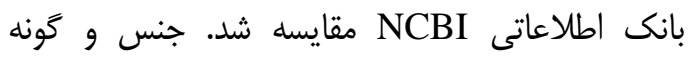

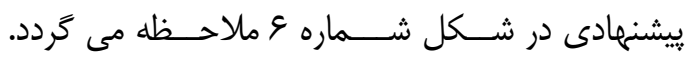

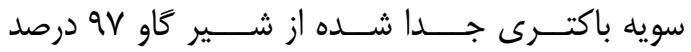

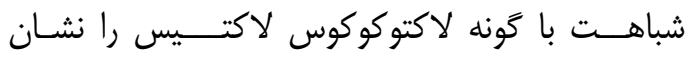
مى دهد.
نتيجه شناسايیى مولكولى سويه بروتئوليتيك انتخاب

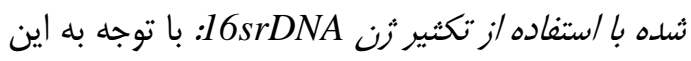

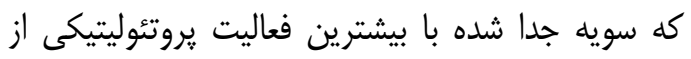

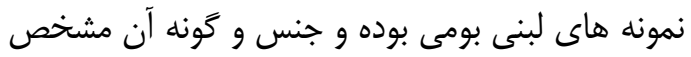

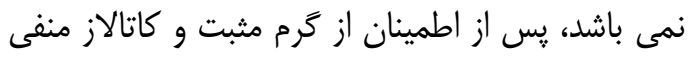
بودن به تشخيص جنس و كَونه آن ها اقدام گَرديد. توالى هاى ارسال شده به فرمت FASTA تبديل شده

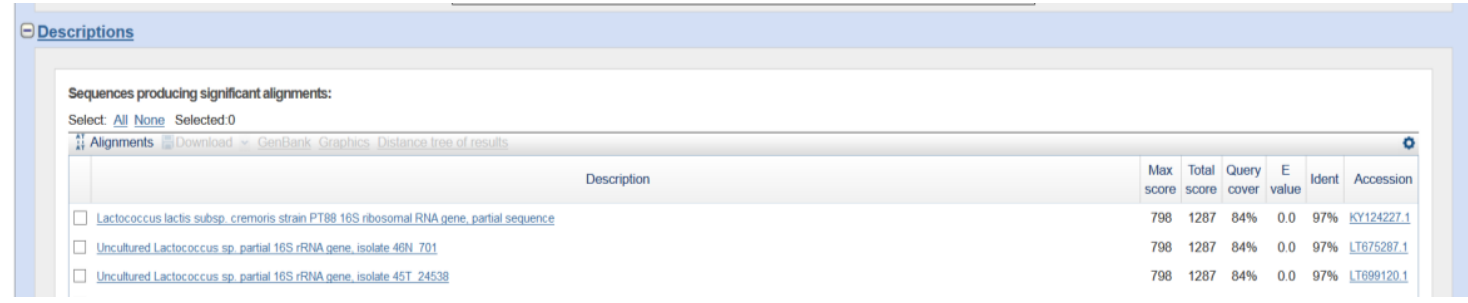

شكل شماره و. نتيجه توالى يابى باكترى داراى بيشترين فعاليت بروتئوليتيكى جدا شده از نمونه شير كاو

هستند(f(I). مطالعات انجام شـــــه جــــت كاهش حساسيت زايى يروتئين هاى كازئين موجود در شير كاو

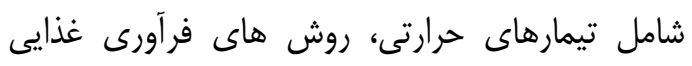

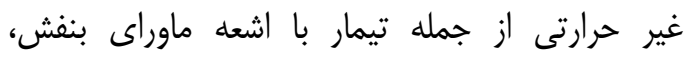

بحث و نتيجلَّيرى حساسيت به شير كاو مى تواند ناشى از واكنش به به به

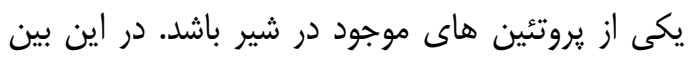

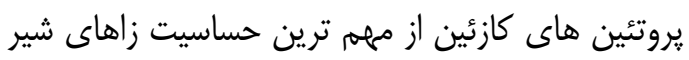


نشان دادند كه تخمير شير بدون هربى توسط باكترى Lactobacillus casei N115 مى تواند آلرزى زايى يروتئين هاى اصلى شير از جمله آلفا كازئين و بتاكازئين را به ميزان قابل تورئ توجهى كائ كاهش

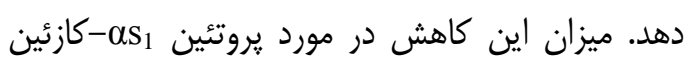

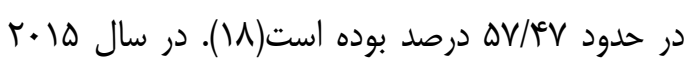

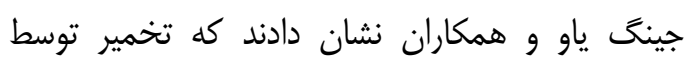

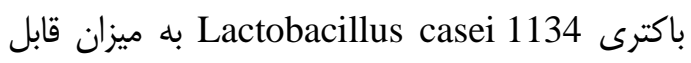

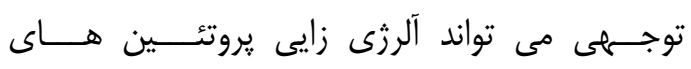

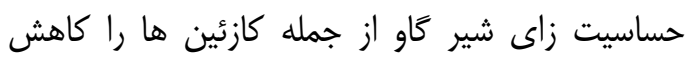

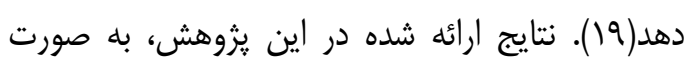

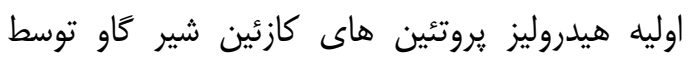
گونه باكترى اسيد لاكتيك لاكتوكو كوس لاكتيس جدا

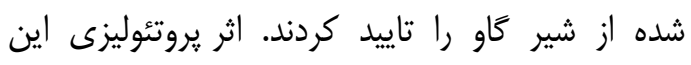

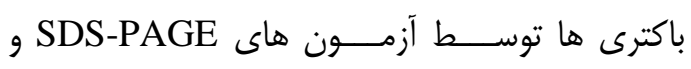
كروماتوگرافى فاز معكوس نيز به به اثبات رسيد. با توجه به نتايج آزمون الايزاى رقابتى، فعاليت يروتئوليتيكى فئي

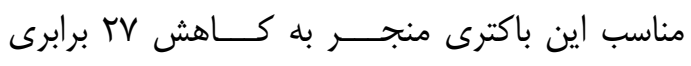
حساسيت يروتئين مئي

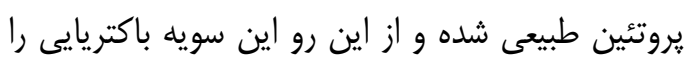

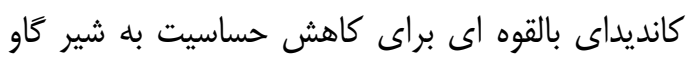
معرفى مى كند.

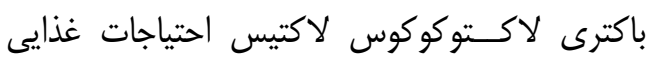

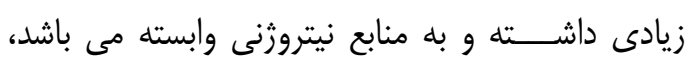

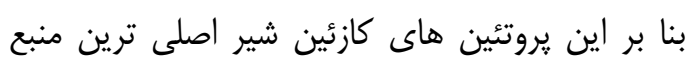

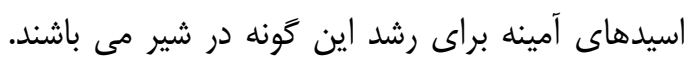

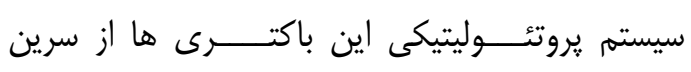

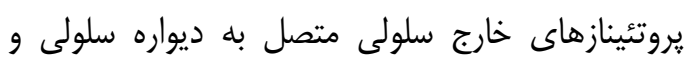
ييتيدازهاى مختلف تشكيل شده كه اسيدهاى آمينه

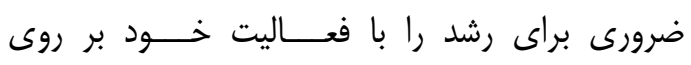

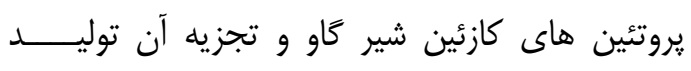

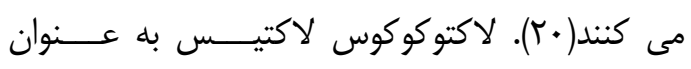

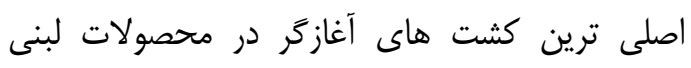
تخميرى از جمله ينير و توليدكننده تركيبات معطر استفاده شده كه اهميت صنعتى و اقتصادى اين باكترى

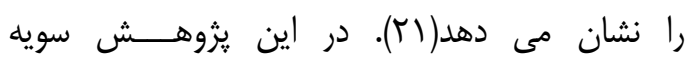

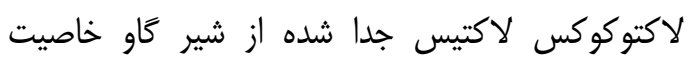
كاهش دهندگى حساسيت به يروتئين كازئين شير كاو
فراصوت با شدت بالا و يا تركيبى از روش هاى مختلف

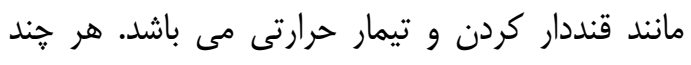

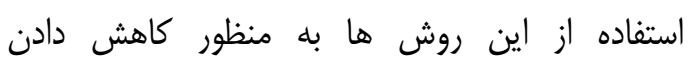
حساسيت زايى مواد غذايى در سال هاى اخير بسيار

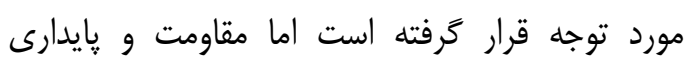

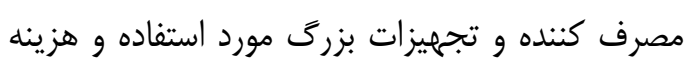

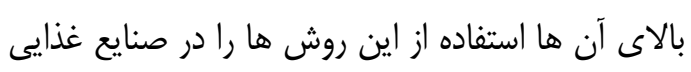

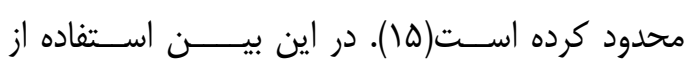
باكترى هاى اسيد لاكتيك به منظور كاهش حساسيت بله شير كاو نقش موثرترى را به خود اختصاص داص داده اند.

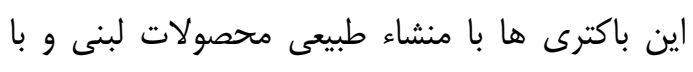

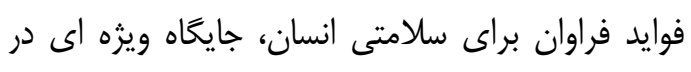

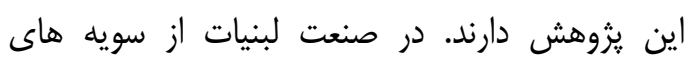

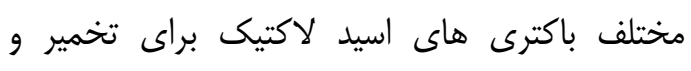

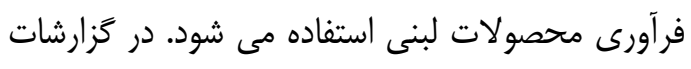

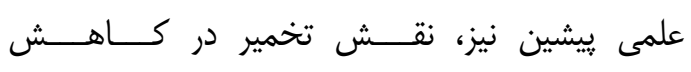

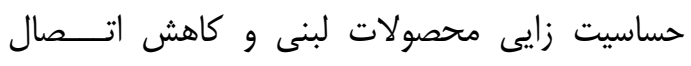

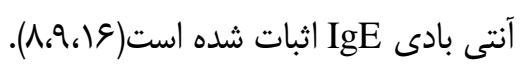

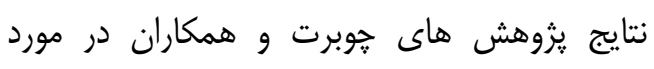

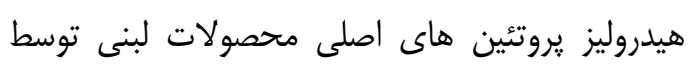

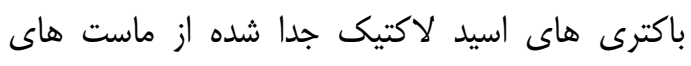

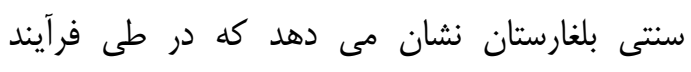

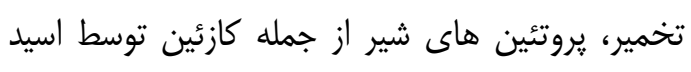

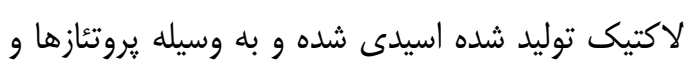
ييتيدازهاى باكتريايى هيدروليز مى شوند. اين يروتئوليز

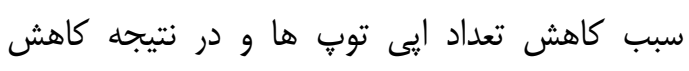

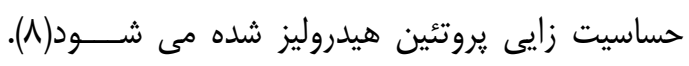

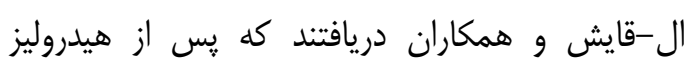

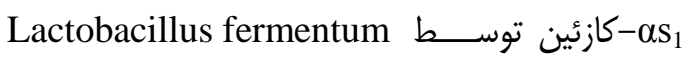
IFO 3956 تشخيص و اتصال IFE به اين يروتئين تشارين از مخزن سرمى \\ بيمار داراى حساسيت به شير كاو به مقدار قابل توجهى كاهش مى يابد(سار).


احمدوا و همكاران انجام شد نشان داد كه هيدروليز توسط Lactobacillus helveticus A75 باعث همان

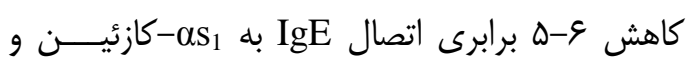

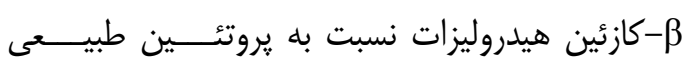

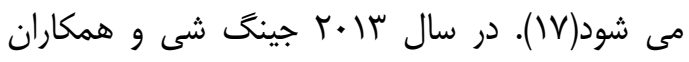




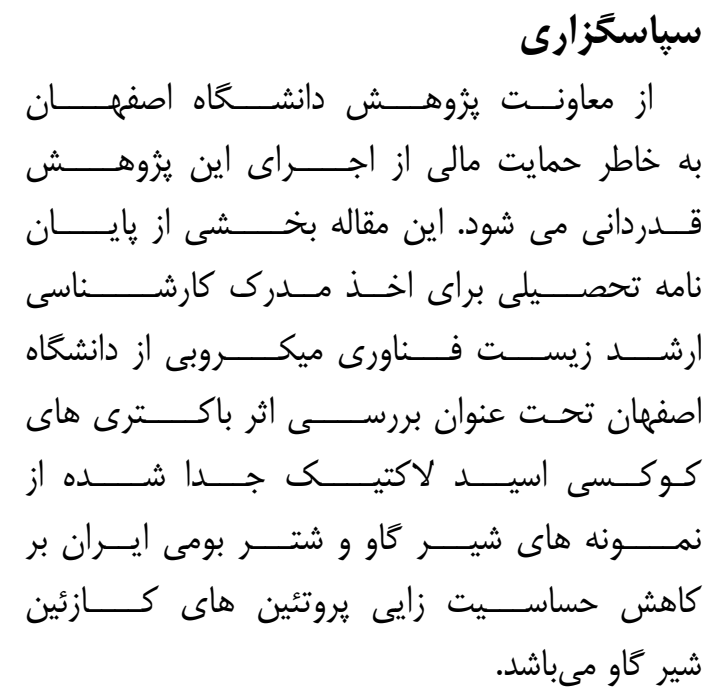

\section{References}

1.Nwaru BI, Hickstein L, Panesar SS, Muraro A, Werfel T, Cardona V, et al. The epidemiology of food allergy in Europe a systematic review and metaanalysis. Allergy 2014;69:62-75, Doi: 10.1111/all.12305.

2.Barzegar S, Rosita A, Pourpak Z, Bemanian MH, Shokouhi R, Mansouri M, et al. Common causes of anaphylaxis in children: the first report of anaphylaxis registry in Iran. World Allergy Org J 2010;3:9-13, Doi: 10.1097/WOX.

3.Crittenden RG, Bennett LE. Cows milk allergy a complex disorder. J Am College Nut 2005;24:582-91.

Doi:10.1080/07315724.

4.Host A, Halken S. A prospective study of cow milk allergy in Danish infants during the first 3 years of life. Allergy 1990;45:587-96. Doi: 10.111/j.1398-9995.

5.Jarvinen KM, Chatchatee P, Bardina L, Beyer K, Sampson HA. IgE and IgG binding epitopes on $\alpha$-lactalbumin and $\beta$ lactoglobulin in cow's milk allergy. Int Arch Allergy Immun 2001;126:111-118, Doi: $10.1159 / 000049501$.

6. Schulmeister U, Hochwallner $\mathrm{H}$, Swoboda I, Focketejkl M, Geller B, Nystrand $\mathrm{M}$, et al. Cloning expression and mapping of allergenic determinants of $\alpha_{\mathrm{S} 1}$ casein a major cows milk allergen. J Immun 2009;182:7019-29. Doi: 10.4049.

7.Verhoeckx KC, Vissers YM, Baumert JL, Faludi R, Feys M, Flanagan S, et al. Food

$$
\begin{aligned}
& \text { را به صورت تجربى نشان داد. اين سويه مى تواند به } \\
& \text { عنوان كشت استارتر اصلى يا الحاقى براى توليد }
\end{aligned}
$$

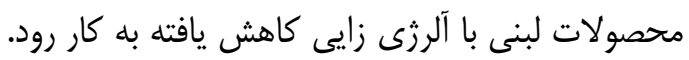

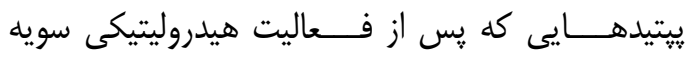

$$
\begin{aligned}
& \text { لاكتوكوكوس بر روى بروتئين هاى كازئين شير توليد } \\
& \text { مى شوند هم جنين مى توانند به عنوان اجزاى تشكيل }
\end{aligned}
$$

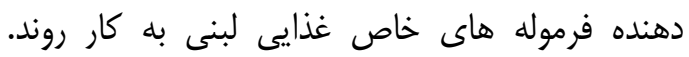

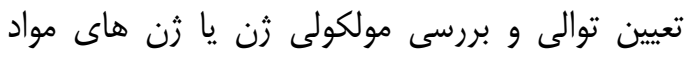

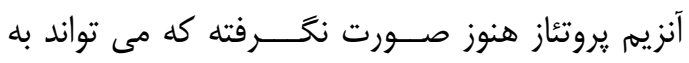

$$
\begin{aligned}
& \text { عنوان يك يِيشنهاد براى ادامه كارهاى تحقيقاتى بعدى } \\
& \text { در آينده ارائه كردد. }
\end{aligned}
$$

processing and allergenicity. Food Chem Toxicol 2015;80:223-40. Doi: 10.1016.

8. Tzvetkova I, Dalgalarrondo M, Danova $\mathrm{S}$, Iliev I, Ivanova I, Chobert J, et al. Hydrolysis of major dairy proteins by lactic acid bacteria from Bulgarian yogurts. J Food Biochem 2007;31:680-702. Doi: 10.1111.

9.Donkor ON, Henriksson A, Vasiljevic T, Shah NP. Proteolytic activity of dairy lactic acid bacteria and probiotics as determinant of growth and in vitro angiotensinconverting enzyme inhibitory activity in fermented milk. Lait 2007; 87:21-38, Doi: 10.1051/lait: 2006023.

10. Ghaish S, Ahmadova A, Hadji I, El Mecherfi KE, Bazukyan I, Choiset Y, et al. Potential use of lactic acid bacteria for reduction of allergenicity and for longer conservation of fermented foods. Trends Food Sci Technol 2011;22:509-516. Doi:10.1016.

11. Deutsch SM, Molle D, Gagnaire V, Piot M, Atlan D, Lortal S. Hydrolysis of sequenced $\beta$-casein peptides provides new insight into peptidase activity from thermophilic lactic acid bacteria and highlights intrinsic resistance of phosphopeptides. Appl Environ Microb 2000; 66:5360-5367. Doi: 10.1128.

12. Pescuma M, Hebert EM, Mozzi F, Valdez G. Hydrolysis of whey proteins by Lactobacillus acidophilus, Streptococcus thermophilus and Lactobacillus delbrueckii 
ssp. bulgaricus grown in a chemically defined medium. J Appl Microb 2007; 103:1738-1746. Doi:

10.1111 .

13. Ghaish S, Rabesona $\mathrm{H}$, Choiset $\mathrm{Y}$, Sitohy M, Haertle T, Chobert JM. Proteolysis byLactobacillus fermentum IFO3956 isolated from Egyptian milk products decreases immune reactivity of $\alpha \mathrm{s}_{1}$ casein. J Dairy Res 2011; 78:203-210. Doi: 10.1017/S0022029911000100.

14.Caira S, Addeo F, Pinto G, Picariello G, Chianese L, Cuollo M, et al. Allergenicity of milk proteins. Intech Open Access Publisher 2012; 2:123-7. Doi: 10.5772/52086.

15. Bu G, Luo Y, Chen F, Liu K, Zhu T. Milk processing as a tool to reduce Cow's milk allergenicity a mini review. Dairy Sci Technol 2013; 93:211-23. Doi: 10.1007/s13594-013-0113-x.

16. Moulay M, Aggad H, Benmechernene Z, Guessas B, Henni DE, Kihal M. Cultivable lactic acid bacteria isolated from Algerian raw goat's milk and their proteolytic activity. World J Dairy Food Sci 2006; $1: 12-8$.
17. Ahmadova A, Ghaish SH, Choiset Y, Rabesona H, Drouet M, Chobert J, et al. Modification of $\operatorname{IgE}$ binding to $\beta$ and $\alpha \mathrm{s}_{1}$-caseins by proteolytic activity of Lactobacillus helveticus A75. J Food Biochem 2013; 37:491-5. Doi: 10.1111. 18. Shi J, Luo Y, Xiao Y, Li Z, Xu Q, Yao M. Effects of fermentation by Lactobacillus casei on the antigenicity and allergenicity of four bovine milk proteins. Int Dairy $\mathbf{J}$ 2014;35:75-80. Doi: 10.1016.

19. Yao M, Xu Q, Luo Y, Shi J, Li Z. Study on reducing antigenic response and IgE-binding Inhibitions of four milk proteins of Lactobacillus casei 1134. J Sci Food Agric 2015; 95:1303-12. Doi: 10.1002 .

20. Meijer W, Marugg JD, Hugenholtz J. Regulation of proteolytic enzyme activity Lactococcus lactis. Appl Environ Microb 1996;62:156-61. Doi: 10.1143.

21. Desmasures N, Mangin I, Corroler D, Gueguen M. Characterization of lactococci isolated from milk produced in the Camembert region of Normandy. J Appl Microb 1998;85:999-1005. Doi:10.1111. 


\title{
Investigation of Proteolytic Ctivity of Lactococcus lactis in Reducing Cow's Milk Caseins Allergenicity
}

\author{
Kordesedehi $R^{l}$, Taherikafrani $A^{{ }^{*},}$, Rabbanikhorasgani $M^{2}$
}

(Received: January 12, 2017

Accepted: April 5, 2017)

\begin{abstract}
Introduction: Bovine milk is the first and most common cause of food allergy in early childhood with a prevalence rate of about 2$7 / 5 \%$. The milk coagulum consists of four proteins $\alpha_{\mathrm{S} 1}, \alpha_{\mathrm{S} 2}, \beta$ and $\kappa$-caseins. Cow's milk caseins play a basic role in persistence of cow's milk allergy (CMA) in children. Proteolytic system of lactic acid bacteria (LAB) has the ability to hydrolyze antigenic epitopes of milk proteins and, as a result, can reduce allergy to caseins. The aim of this study was to isolate the best lactic acid bacteria strain from cow's milk samples in order to reduce bovine milk caseins allergenicity.
\end{abstract}

Materials \& Methods: In the present study, after isolation of 30 cocci $\mathrm{LAB}$ from 20 Iranian cow's milk samples, the effect of proteolytic activity of these bacteria on milk caseins was investigated by SDSPAGE and RP-HPLC techniques. Subsequently, among the 15 strains with protease activity, the binding ability of native and hydrolyzed $\alpha_{\mathrm{S} 1}$-casein to $\operatorname{IgE}$ sera from cow's milk allergic patients was determined by competitive ELISA test.

Findings: After accomplishing biochemical tests including gram staining and catalase test, molecular identification of the strains was done by $16 \mathrm{~s}$ rRNA fragment sequencing. The obtained results suggested that Lactococcus lactis was able to hydrolyze casein fractions in both skim milk and sodium caseinate and could reduce allergenicity of bovine milk $\alpha_{\mathrm{S1}^{-}}$ casein.

Discussion \& Conclusions: Our conclusion demonstrated that the isolated Lactococcus lactis strain from cow's milk samples can be used as a main or adjunct starter culture in dairy products to reduce immunoreactivity of cow's milk caseins.

Keywords: food hypersensitivity, casein, lactic acid bacteria, competitive ELISA.

1.Dept of Biotechnology, Faculty of Advanced Sciences and Technologies, Isfahan University, Isfahan, Iran

2.Dept of Biology, Faculty of Science, Isfahan University, Isfahan, Iran

*Corresponding author Email: a.taheri@ast.ui.ac.ir 